\title{
L'ambiente visto dall'interno. Abitare il cambiamento climatico
}

Giovanna Ramaccini

\section{Abstract}

Il contributo propone una riflessione sulla crisi ambientale che sta colpendo il pianeta, soffermandosi sul potenziale immaginativo offerto da differenti metodi di comunicazione (dal graphic design al sound design, dalle installazioni architettoniche alle simulazioni infografiche) e sottolineando l'importanza che questi rivestono nella connessione dei diversi livelli di informazione, con particolare riferimento alla capacità di tradurre dati astratti in immagini evocative dei potenziali effetti sulla quotidianità. In tal senso il contributo si concentra sul tema dell'abitare che, come illustrato, appare sempre più orientato a una vita condotta all'interno di ambienti protetti, separati da un esterno ostile.

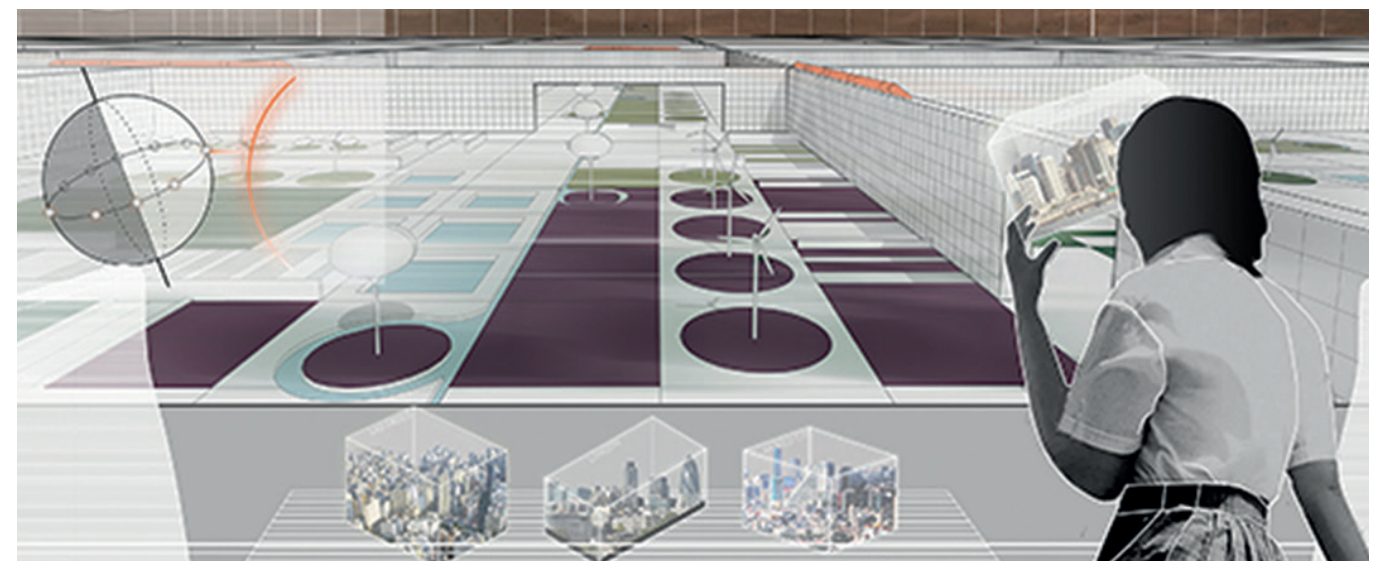




\section{Introduzione}

Nella decade passata milioni di persone sono state sradicate dalle proprie case a causa di ingenti disastri naturali che hanno richiesto assistenza e mobilitazione immediate. Dall'uragano Katrina negli Stati Uniti (2005) al terremoto e allo tsunami in Giappone (20 I I), dal tifone Haiyan nelle Filippine (2013) al terremoto in Nepal (20I5), dalla tempesta di sabbia in Turchia (20I5) al terremoto in Italia (2016), le conseguenze dei fenomeni naturali estremi che si sono verificati sono comparse con tutta la loro potenza in immagini fotografiche aeree che hanno mostrato aree interamente riconfigurate [Vinitsky 2017]. II filosofo della scienza Peter Galison e la storica dell'arte Caroline A. Jones (sebbene con specifico riferimento alle immagini prodotte sulla scia del drammatico disastro ambientale legato alla piattaforma petrolifera Deepwater Horizon) sostengono nella loro analisi che le 'tecnologie del visibile' (quali spettacolari immagini satellitari, tragiche fotografie ravvicinate, penetranti immagini in diretta) possono catturare l'attenzione dei fruitori, ma non riescono a comunicare gli effetti più profondi del disastro [Galison, Jones 2010, pp. 49-5I] (fig. I). II carattere drammatico di simili rappresentazioni trasmette una sensazione di totale impotenza fino a giungere alla situazione paradossale in cui l'estetica dei fatti è tale da anestetizzare l'azione. Al contempo la comunicazione dei fenomeni naturali estremi, con particolare riferimento ai fenomeni naturali correlati al cambiamento climatico, viene affidata a un linguaggio scientifico esperto e pur osservandone quotidianamente gli effetti (quali l'aumento delle temperature, lo scioglimento dei ghiacciai o l'innalzamento del livello delle acque) non si ha l'effettiva percezione del problema nella sua complessità. È in questo senso che in un'era ossessionata dalla comunicazione d'impatto da un lato e dall'abuso di tecnicismi dall'altro, diventa di fondamentale importanza un livello di comunicazione volto non tanto a trasmettere informazioni e misurazioni 'esatte' dei fenomeni previsti, ma piuttosto a trasmettere il valore incommensurabile degli effetti potenziali che tali previsioni comporterebbero nella vita di ciascuno. Così come dimostrato da una serie di recenti esperienze che, seppure eterogenee per gli strumenti impiegati, sono accomunate dall'intento di riportare a una dimensione di vissuto quotidiano

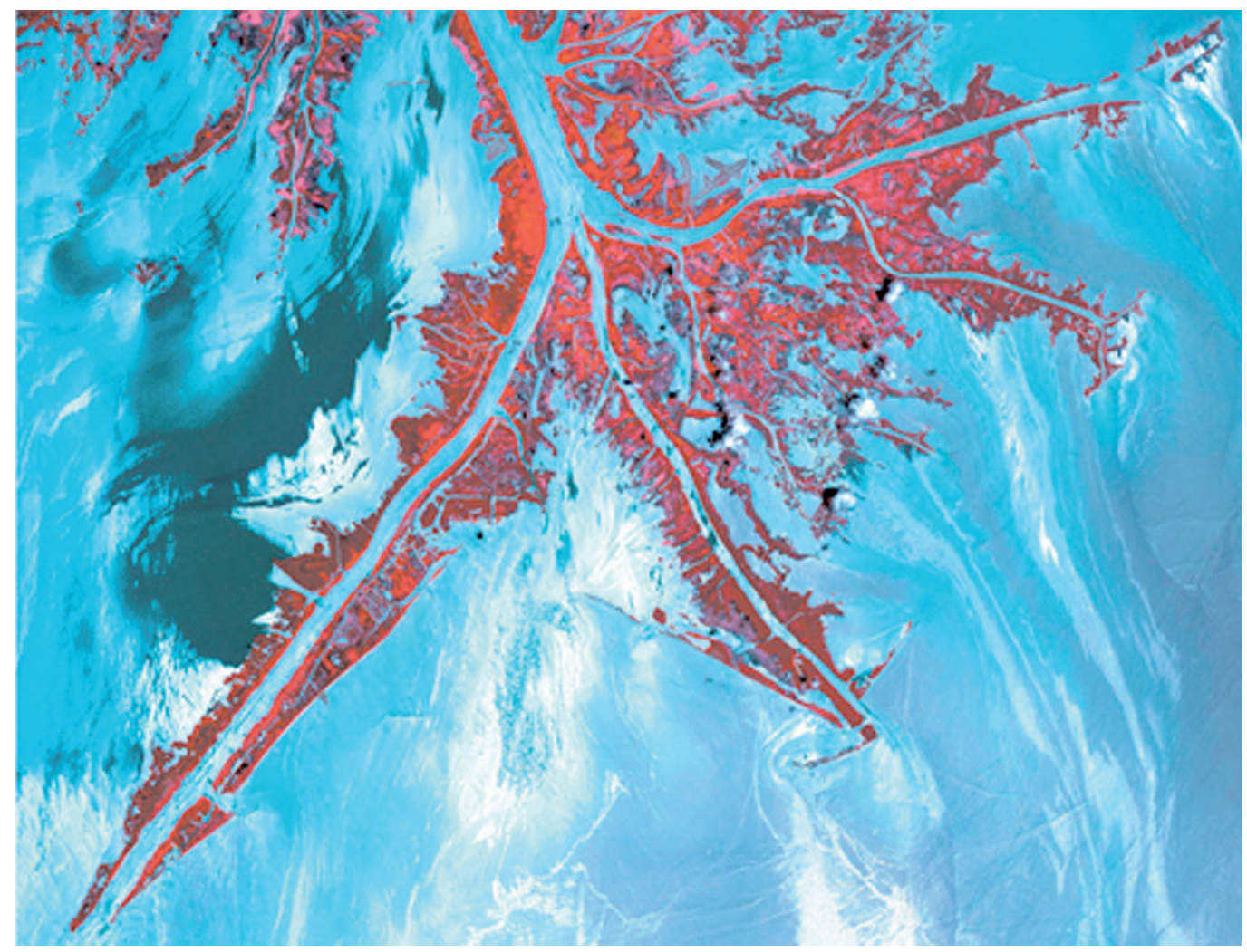


un problema apparentemente astratto, rendendone tangibili gli effetti possibili e sollecitando azioni concrete di cambiamento. Tra queste Warming Stripes, il pattern grafico ideato dal climatologo britannico Ed Hawkins e composto da bande verticali che, attraverso variazioni cromatiche blu e rosse, associate rispettivamente a temperature inferiori o superiori alla media, illustrano in maniera intuitiva l'andamento crescente della temperatura media globale negli anni tra il I 870 e il 20 I7 [ I] (fig. 2); Totemy, linstallazione a opera della designer polacca Alicja Biała e dell'architetto polacco Iwo Borkowicz, in cui i dati sul cambiamento climatico vengono reinterpretati in pattern grafici che caratterizzano le superfici di sei imponenti totem posizionati in prossimità della torre Bałtyk nella città di Poznań (fig. 3); Acqua Alta: En Clave de Sol, l'installazione di sound design presentata dall'artista argentino Tomàs Saraceno in occasione della $58^{\circ}$ Esposizione Internazionale d'Arte, in cui, sovrapponendo a una partitura musicale il grafico relativo all'alta marea prevista a Venezia nei successivi cento anni, viene immaginato il suono delle sirene d'allarme nel contesto di una città completamente sommersa (fig. 4); $+1,5^{\circ} \mathrm{C}$ Lo cambia todo, la campagna di videosimulazione promossa da WWF insieme al Museo del Prado, in cui alcune delle opere più note della collezionate del
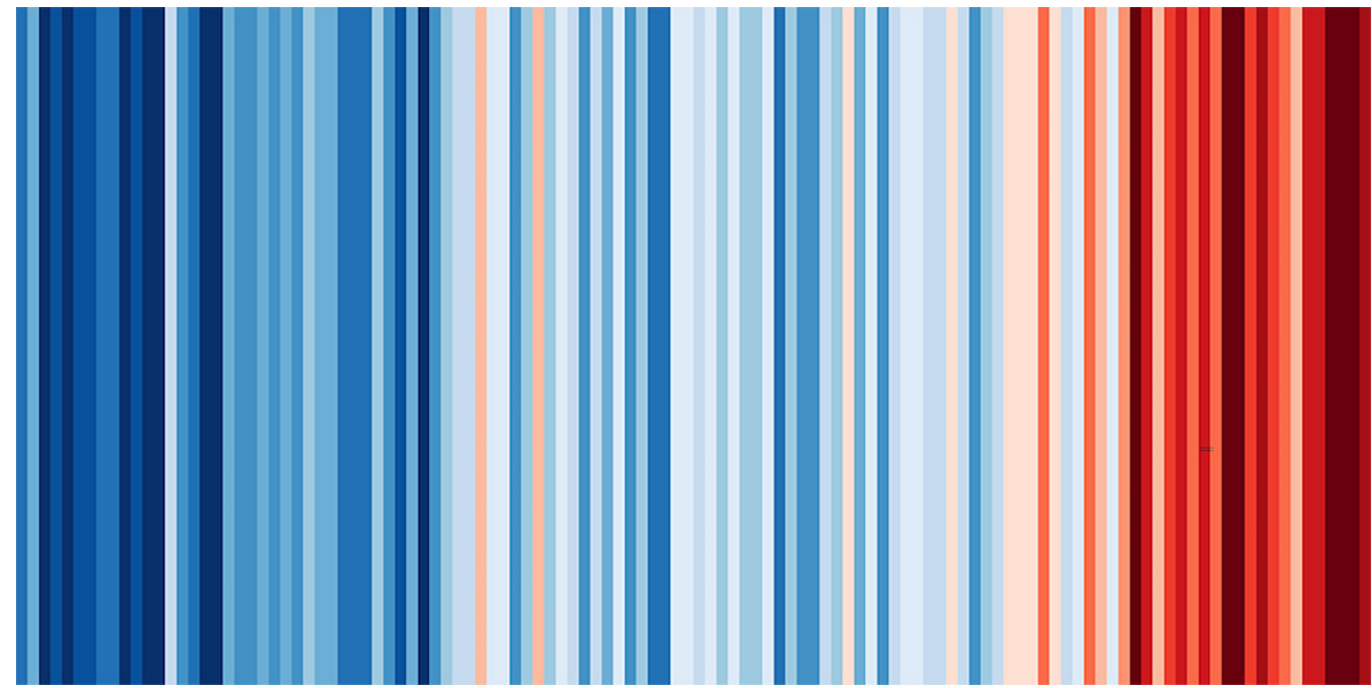

Fig. 3. Alicja Biała e Iwo Borkowicz, Totemy, particolare dell'installazione.

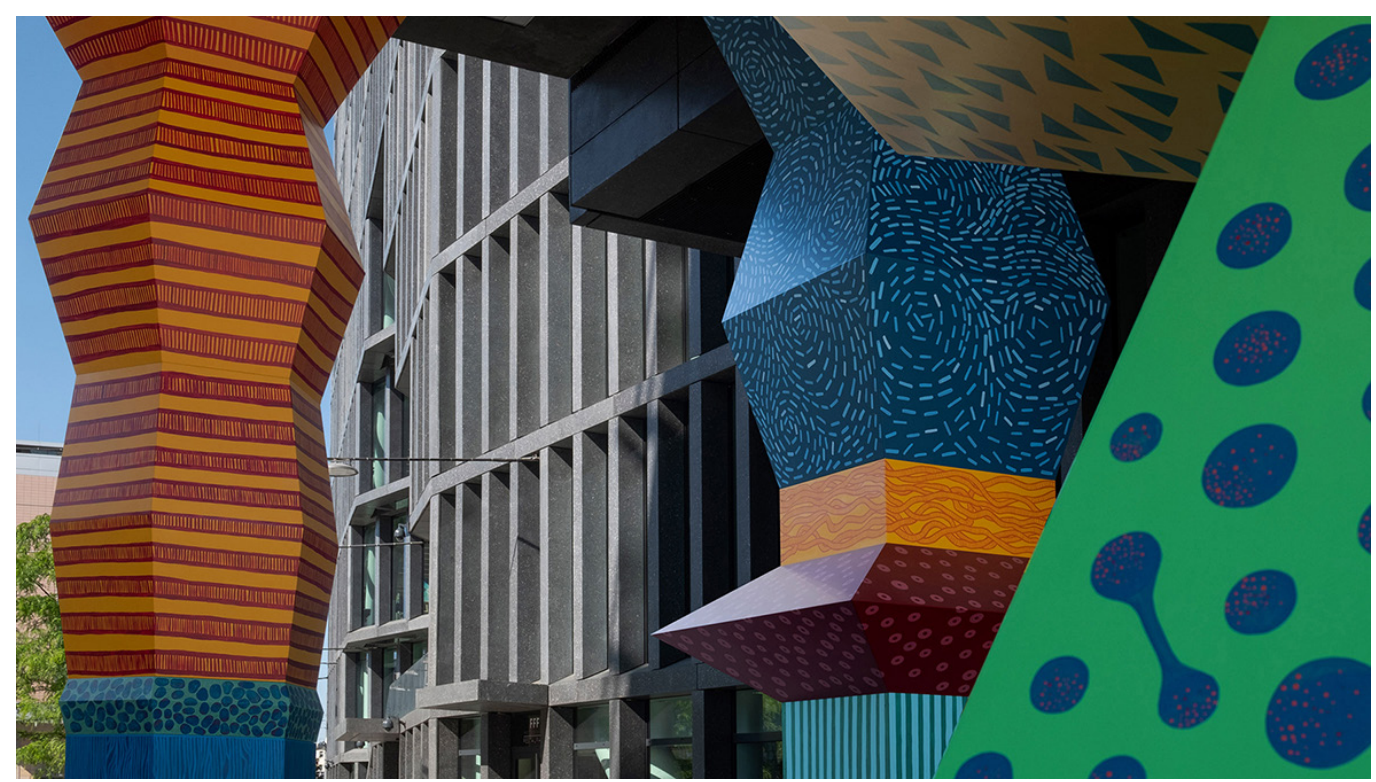


museo spagnolo vengono immaginate in un futuro in cui la temperatura sul pianeta subirà un aumento di I,5 ${ }^{\circ} \mathrm{C}$ : una cifra apparentemente trascurabile ma tale da sommergere Filippo IV a cavallo nell'omonimo ritratto firmato da Diego Velázquez [2] (fig. 5). Infine Flooded London [3], la serie di simulazioni infografiche in cui il gruppo di design digitale Squint Opera immagina la città di Londra nel 2090, illustrando ai cittadini come un concetto apparentemente astratto, quale il cambiamento climatico, possa influenzare la vita quotidiana: e cosi, l'aumento catastrofico delle temperature e del livello del mare concederanno la possibilità di un tuffo all'interno della navata allagata della cattedrale di San Paolo (fig. 6)

Fig. 4. Tomàs Saraceno,

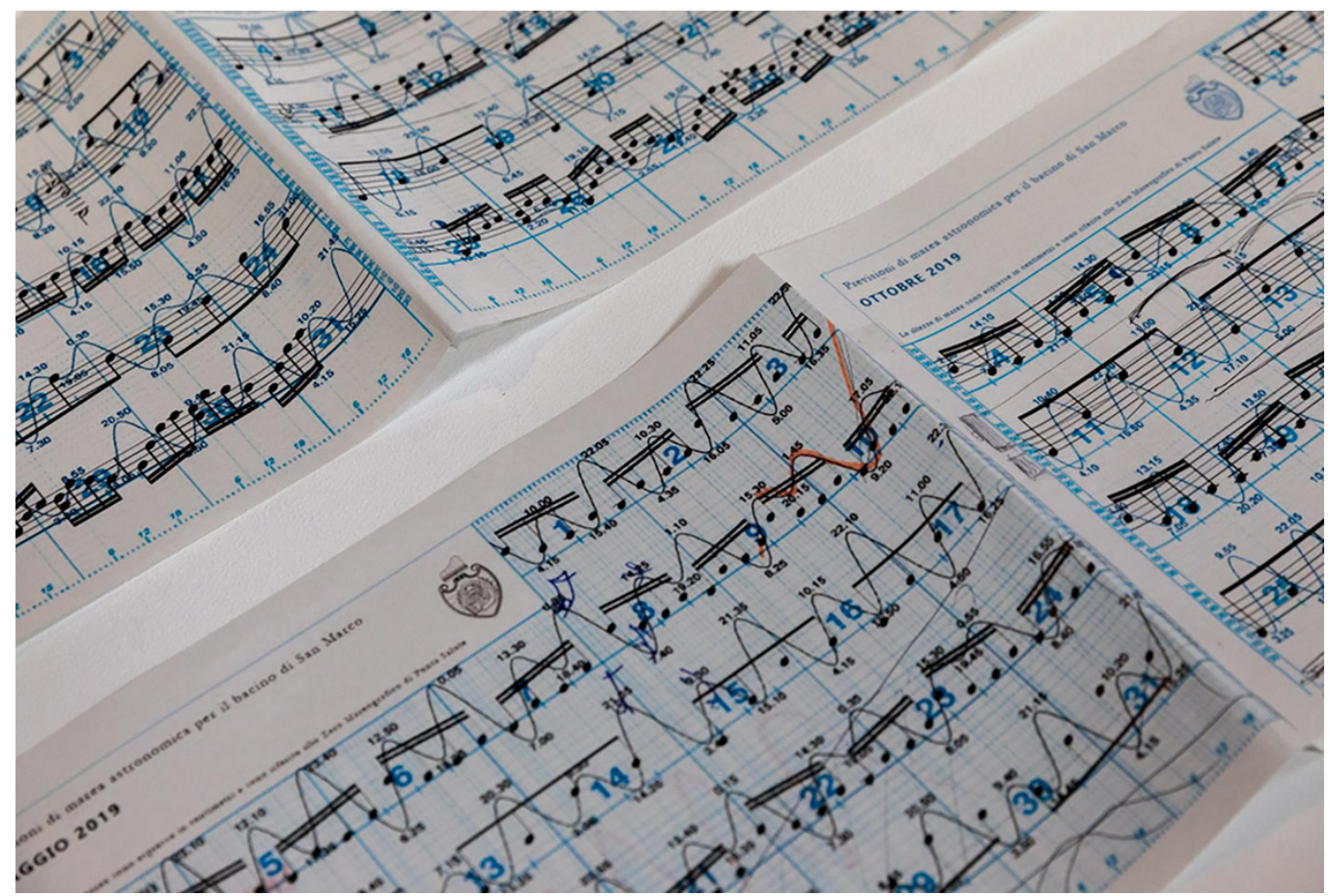

\section{Vivere all'interno}

Nel 1928 Gio Ponti dedicava l'editoriale d'apertura del primo numero della rivista Domus al tema La casa allitaliana in cui affermava come il carattere peculiare della cultura nazionale fosse espresso dalla ricerca di un proprio paesaggio domestico, le cui caratteristiche erano individuate nell'abolizione di ogni distinzione tra interno ed esterno. Ė infatti lo stesso Gio Ponti ad affermare che "la casa all'italiana non è il rifugio, imbottito e guarnito, degli abitatori contro le durezze del clima come è delle abitazioni d'oltralpe ove la vita cerca, per lunghi mesi, riparo dalla natura inclemente: la casa all'italiana è come un luogo scelto da noi per godere in vita nostra, con lieta possessione, le bellezze che le nostre terre e i nostri cieli ci regalano in lunghe stagioni. Nella casa all'italiana non vi è grande distinzione fra esterno e interno [...]. Dall'interno la casa all'italiana riesce all'aperto con i suoi portici e le sue terrazze, con le pergole e le verande, con le logge ed i balconi, le altane e i belvederi, invenzioni tutte confortevolissime per l'abitazione serena e tanto italiane che in ogni lingua sono chiamate con nomi di qui" [Ponti 1928, p. I 8; Irace 2019, pp. 40-46].

Eppure, a distanza di circa un secolo, le previsioni future sull'ambiente, dall'insorgere di temperature elevate alla diffusione di epidemie, rendono questa interpretazione praticamente inverosimile. Basti pensare alle previsioni legate l'aumento del livello delle acque. New York, Rio de Janeiro, Alessandria d'Egitto, Pisa, Ravenna, Venezia, Bari sono solo alcune delle città situate in prossimità della costa atlantica, mediterranea, tirrenica o adriatica che, secondo 
uno studio pubblicato dall'organizzazione internazionale Climate Central [4], nel corso del prossimo decennio, con un aumento della temperatura dai 2 ai 4 gradi centigradi, verranno sommerse dalle acque (fig. 7). Allora la casa del futuro, sia essa sulle coste della penisola e in altre parti del mondo, più che aderire alla descrizione di Gio Ponti, si avvicina all'interpretazione del filosofo francese Gaston Baschelard, owero la casa rifugio, tana o guscio. $\grave{E}$ così che azioni quali il limitare, il recingere, o il circoscrivere, costitutive dello spazio interno, vengono mosse da un sentimento di "claustrofilia" [Fachinelli 1983, pp. 62-64] dettato dalla "ricerca del chiuso" e attuate in opposizione a una regione esterna vista come pericolosa, ostica e letteralmente invivibile.

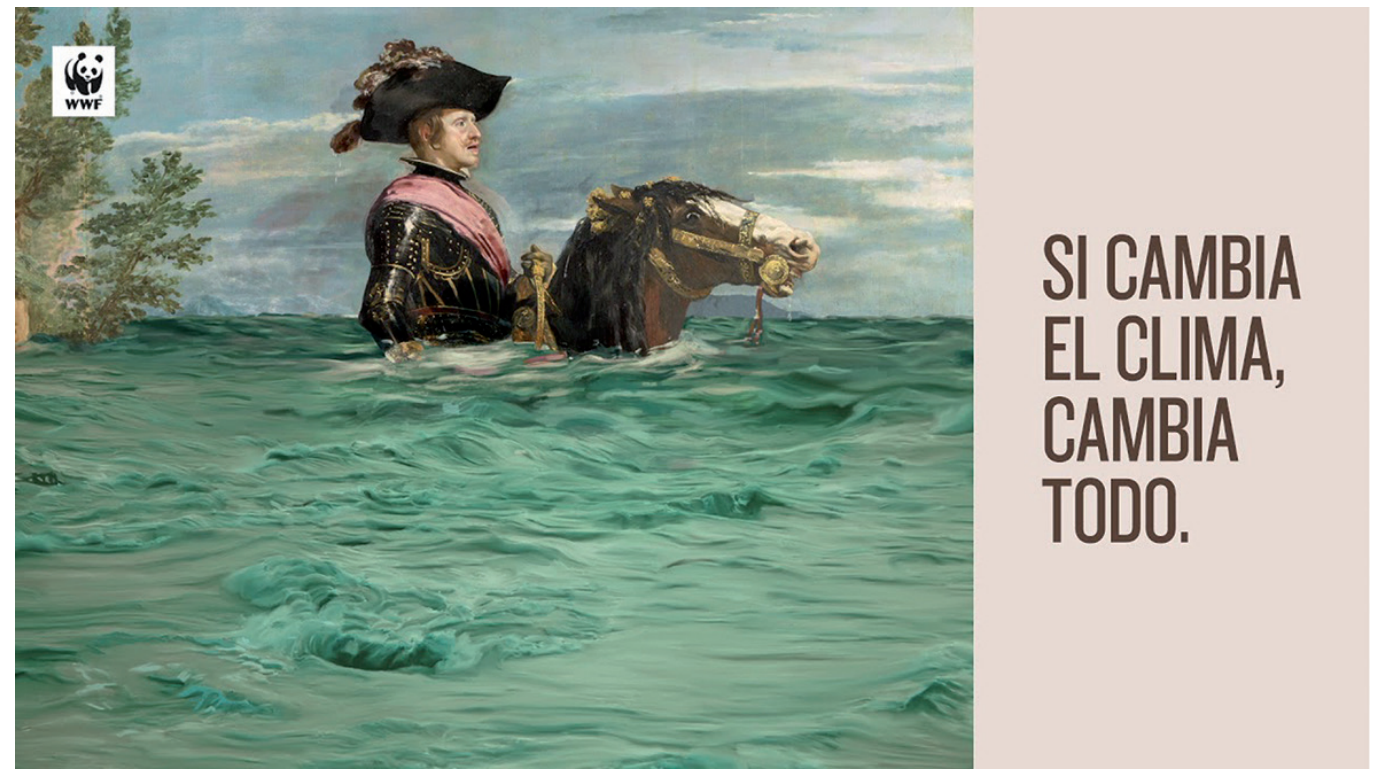

In questo senso appare estremamente interessante il progetto Airpocalypse firmato da El Hadi Jazairy e pubblicato all'interno del volume Geostories. Another Architecture for the Environment [Ghosn, Jazairi 20 I 8]. In progetto si configura come una risposta visionaria alla crisi legata all'inquinamento dell'aria che ha colpito la città di Pechino nel 2014 e che continua a colpire in modo particolare molte delle aree più industrializzate della Cina. Nel gennaio 20 I 4, la città di Pechino è stata soggetta a ventisei giorni consecutivi di smog intenso: l'aria ha assunto una densità tale da impedire la vista del sole. Sono ormai note le immagini della folla accalcata attorno a un maxischermo in piazza Tienamen in attesa della trasmissione del sorgere del sole. Un evento che è stato divulgato dalla stampa internazionale con in titolo "L'alba sarà trasmessa in televisione!" e che è emblematico del rischio ormai concreto di non poter considerare la possibilità di respirare come un'owietà. Allora, considerando le condizioni atmosferiche di una città colpita da un pesante assalto di smog, come immaginare le strutture necessarie a rendere possibile la vita su una terra privata di sole e di atmosfera? La risposta veicolata da Airpocalypse consiste nel racchiudere all'interno di confini limitati la popolazione mondiale che occupa le aree urbane. Una megalopoli concepita come un grande interno circoscritto e vivibile, sottoposto al controllo climatico grazie alla presenza di un habitat atmosferico, di una serra, di una biosfera, e di una navicella spaziale. Sul cruscotto della navicella spaziale, una serie di "palle di neve" racchiude alcune scene urbane miniaturizzate, da Chicago a Città del Messico, da Londra a San Paolo, che includono porzioni di paesaggio rinnovabili (fig. 8).

O ancora il progetto Mars Science City (fig. 9), il primo prototipo sulla terra per una vita futura su Marte, sviluppato dallo studio internazionale di progettazione BIG e in corso di 
realizzazione nella città di Dubai [5]. II progetto immagina uno scenario futuro in cui, per proteggere le risorse della terra, l'umanità si trasferirà sul pianeta Marte. Come affrontare l'adattamento al clima e al paesaggio locali, caratterizzati da bassa gravità, bassa pressione, freddo estremo e alti livelli di radiazione? Uno dei modi possibili per riprogettare l'abitare consiste nella costruzione di un grande interno che includa e stratifichi elementi differenti. In particolare si tratta di grandi cupole geodetiche gonfiabili interconnesse (derivanti dalla combinazione di tre tecnologie costruttive ovvero le pressostrutture, le stampanti 3D e le strutture ipogee), in grado di proteggere dalle radiazioni nocive e di custodire un ecosistema a misura d'uomo.

È interessante notare come sia in Airpocalypse sia in Mars Science City la separazione tra un esterno minaccioso e un interno benevolo avviene mediante superfici 'trasparenti'. In questo senso sembrano quanto mai attuali le parole che l'architetto e accademico statunitense Georges Teyssot esprime a proposito dell'"apparente trasparenza" che connota l'architettura del XIX secolo. Una trasparenza "che in realtà è puramente superficiale: giacché gli edifici stessi non sono altro che grandi spazi creatori di 'vasti intérieurs' per la collettività, a tal punto estesi da non avere propriamente esterno" e gli spazi pubblici "diventano altrettanti 'interni', formati in molti casi da edifici di vario tipo" [Teyssot 20 I0, p. 27].

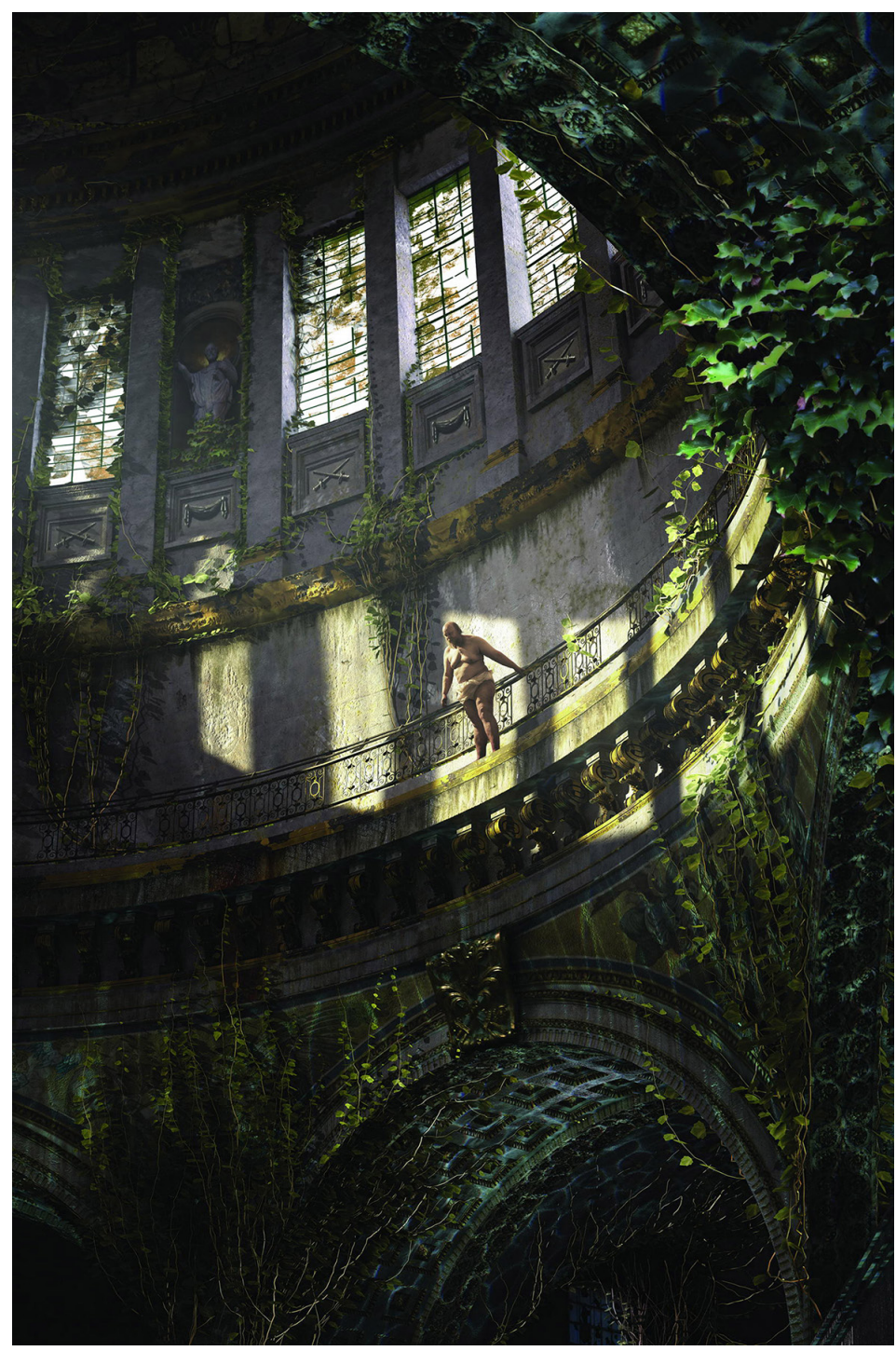




\section{Considerazioni conclusive}

Gli esempi illustrati conducono a gesti radicali che richiedono necessariamente un cambiamento di modelli sinora ritenuti consolidati. In questo senso, per i fini specifici del presente contributo, merita una particolare riflessione il rapporto tra le categorie esterno e interno. Se tradizionalmente la coppia degli opposti pubblico/privato viene associata alla coppia degli opposti esterno/interno, nello scenario futuro, che esclude la possibilità di una vita all'esterno, la coppia pubblico/privato si traduce necessariamente nella coppia interno/"interno dell'interno'. Non solo, ma è proprio in quest'ultimo caso, ovvero a "l'interno dell'interno", che può essere raggiunta una condizione di intimità. Una lettura che è supportata dall'osservazione dell'origine etimologica dell'aggettivo 'intimo'. II termine, come noto, è forma superlativa del termine 'interno' (dal latino intǐmus, forma superlativa dell'aggettivo interior [6]) Volendo quindi offrire un'interpretazione tendenziosa della categoria grammaticale, è proprio grazie al passaggio graduale che denota la forma superlativa, ovvero I'interno dell'interno', che può essere raggiunta una condizione di crescente intimità. Non resta che augurarsi che tale condizione di protezione favorisca nuovi gesti immaginativi per rispondere a un impegno pragmatico ormai ineluttabile. D'altronde, prendendo in prestito il pensiero espresso da Gaston Bachelard: "certo, si avverte che ci si trova davanti a un problema misto di immaginazione e di osservazione. [...] Noi vogliamo semplicemente mostrare che, non appena la vita si stabilisce, si protegge, si copre, si nasconde, l'immaginazione simpatizza con l'essere che abita lo spazio protetto. L'immaginazione vive la protezione, in tutte le sue sfumature di sicurezza, dalla vita nei più materiali gusci fino alle più sottili dissimulazioni del semplice mimetismo delle superfici. Come sogna il poeta Noël Arnaud, l'essere si dissimula sotto la similitudine. Trovarsi al riparo sotto un colore vuol forse dire portare all'estremo, fino all'imprudenza, la tranquillità di abitare?" [Bachelard 1957, p. I63].
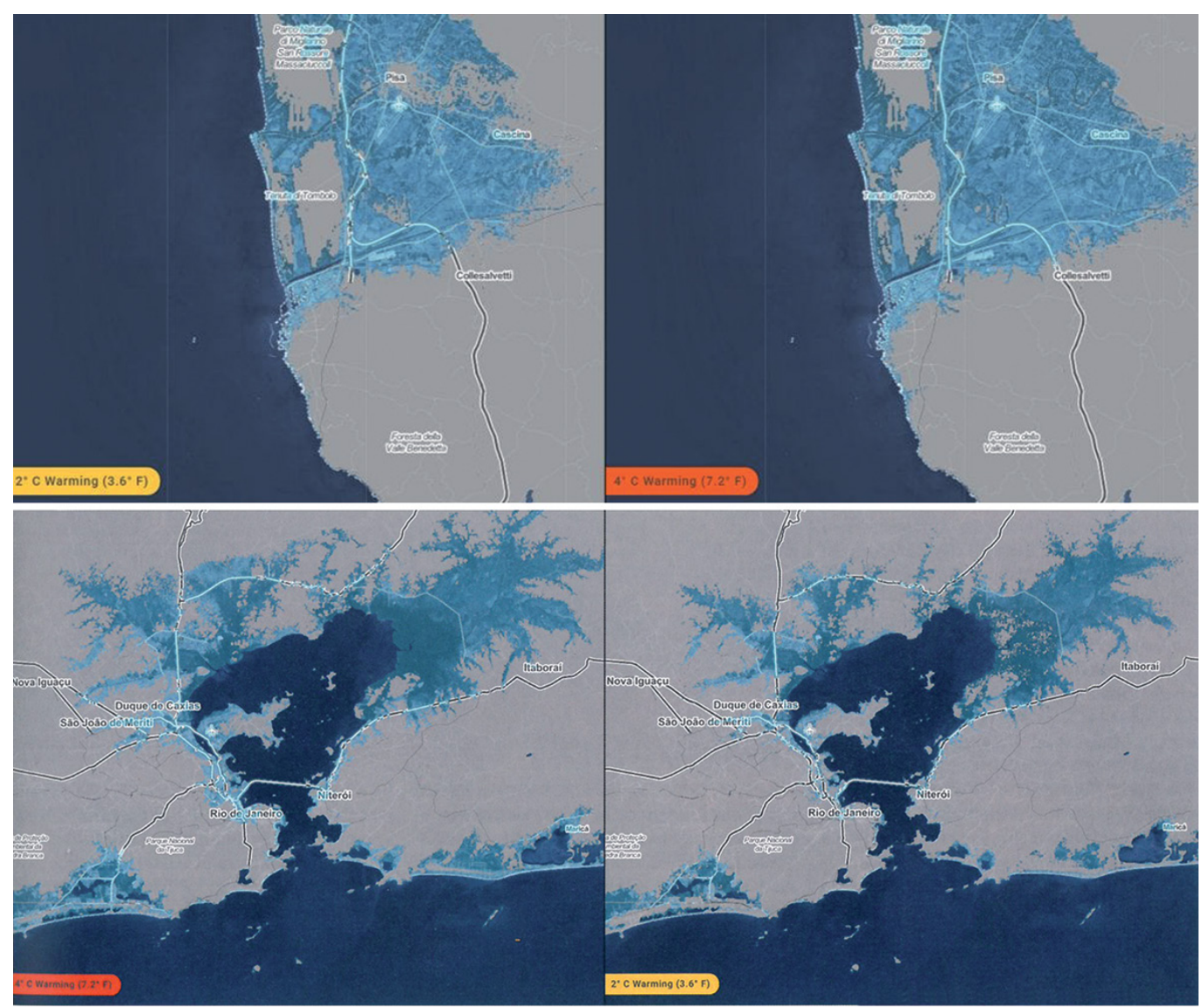

Fig. 8. El Hadi Jazairy,
Airpocalypse, vista della megalopo

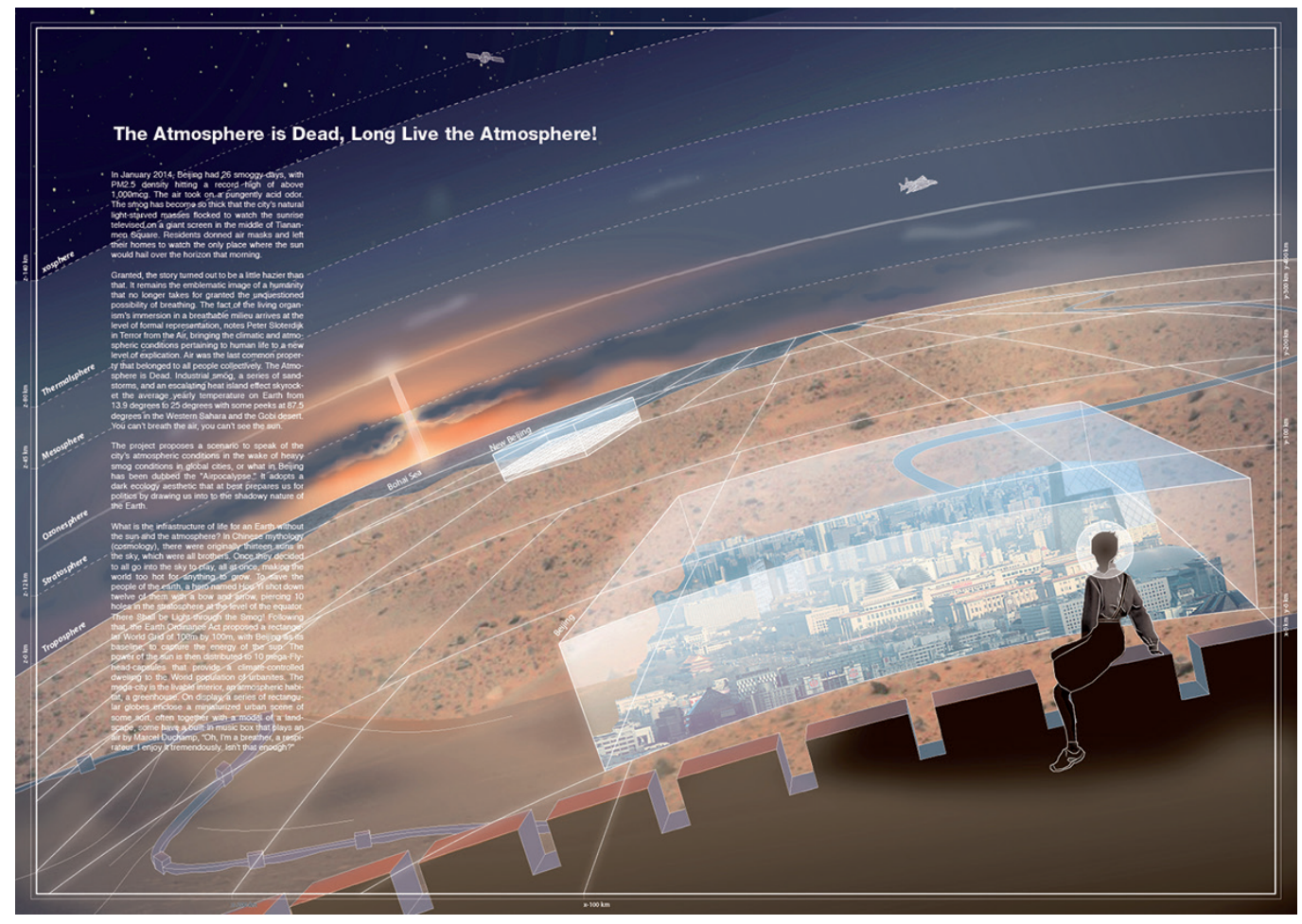

Fig. 9. BIG, Mars Science City, vista delle pressostrutture.

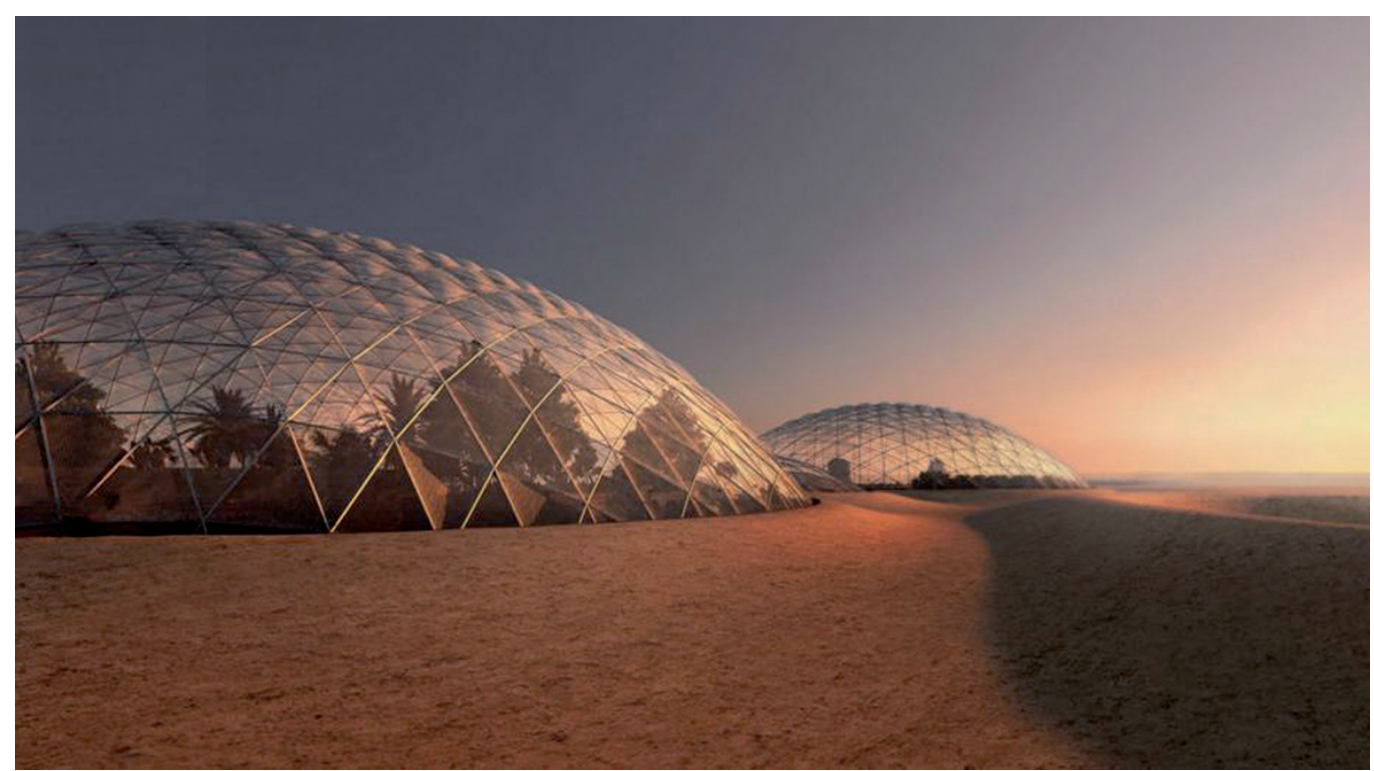




\section{Note}

[I] Le Warming Stripes-identità visiva Waste Mob 20 19: <https://www.youtube.com/watch?v=JzGWvg3NdUc>.

[2] + 1,5 ${ }^{\circ} \mathrm{C}$ Lo cambia todo: <https://www.wwf.es/nuestro_trabajo/clima_y_energia/cumbres_del_clima/cop_25_chile_ madrid/locambiatodo/>.

[3] Flooded London: <https://www.dezeen.com/20 / 9/07/23/flooded-london-squint-opera-climate-change/>.

[4] Surging Seas Extreme Scenario 2100: <https://sealevel.climatecentral.org/maps/P5>.

[5] Mars: <https://big.dk/\#projects-mars $>$.

[6] Intimo (ad voce). In Vocabolario Treccani: <http://www.treccani.it/vocabolario/intimo/>.

\section{Riferimenti bibliografici}

Bachelard Gaston (2015). La poetica dello spazio. Bari: Dedalo. (Ed. orig. La poétique de l'espace. Parigi: Presses Universitaires de France, 1957).

Belardi Paolo (a cura di). (20।8). Riflesso Emergency. Magazine sulla Cultura delle Emergenze.

Bergdoll Barry (20 |9). Abbiamo bisogno della ricerca. Research is needed. In Domus, | 040, p. | | 2 | - | | 27.

Fachinelli Elvio (1983). Claustrofilia. Saggio sull'orologio telepatico in psicanalisi. Milano: Adelphi.

Forino Imma (200 I). L'interno nell'interno. Una fenomenologia dell'arredamento. Firenze: Alinea.

Galison Peter, Jones Caroline A. (20 I0). Unknown Quantities on oil spill imaging. In Artforum International, n. 49, pp. 49-5I.

Ghosn Rania, Jazairy El Hadi (20 I 8). Geostories. Another Architecture for the Environment. New York, Barcellona: Actar.

Irace Fulvio (a cura di). (2019). Storie d'interni. L'architettura dello spazio domestico moderno. Roma: Carocci.

Ponti Gio (1928). La casa allitaliana. In Domus, n. I, p. 7.

Teyssot Georges (20 I0). Soglie e pieghe. Sull'intérieur e l'interiorità. In Casabella, 68I, 200 I, pp. 26-35.

Teyssot Georges (a cura di). (1987). Paesaggio d'interni. Milano: Electa.

Vinitsky Maya (2017). 3.5 Square Meters: Constructive Responses to Natural Disaster. A Research Project and Exhibition. Tel Aviv Museum of Art: HIRMER Publishers.

Weizman Eyal,Weizman Ines (20I4). Before and after. Documenting the architecture of disaster. Strelka Press

\section{Autore \\ Giovanna Ramaccini, Università degli Studi di Perugia, giovanna.ramaccini@unipg.it}

Per citare questo capitolo: Ramaccini Giovanna (2020). L'ambiente visto dall'interno: abitare il cambiamento climatico/The environment from inside. In Arena A., Arena M., Brandolino R.G., Colistra D., Ginex G., Mediati D., Nucifora S., Raffa P. (a cura di). Connettere. Un disegno per annodare e tessere. Atti del $42^{\circ}$ Convegno Internazionale dei Docenti delle Discipline della Rappresentazione/Connecting. Drawing for weaving relationships. Proceedings of the 42th International Conference of Representation Disciplines Teachers. Milano: FrancoAngeli, pp. 3738-3755. 


\title{
The Environment from the Inside. Living the Climate Change
}

\author{
Giovanna Ramaccini
}

\section{Abstract}

The contribution proposes a reflection on the relationship between the environmental crisis that is affecting the planet and the living of the future. In the first part, the attention is focused on the imaginative potential offered by different methods of communication -from graphic design to sound design, from architectural installations to infographic simulations- underlining the importance they have in translating abstract and partial data into sharp and synthetic images, evocative of the potential effects on everyday life. Then the analysis is restricted to the illustration of some experiences that, assuming as hypothesis the perpetrating of an indifferent attitude to the environmental issue, prefigure apocalyptic scenarios, in which life takes place inside environments protected by a hostile exterior, recalling the need for conscious and interconnected design actions.

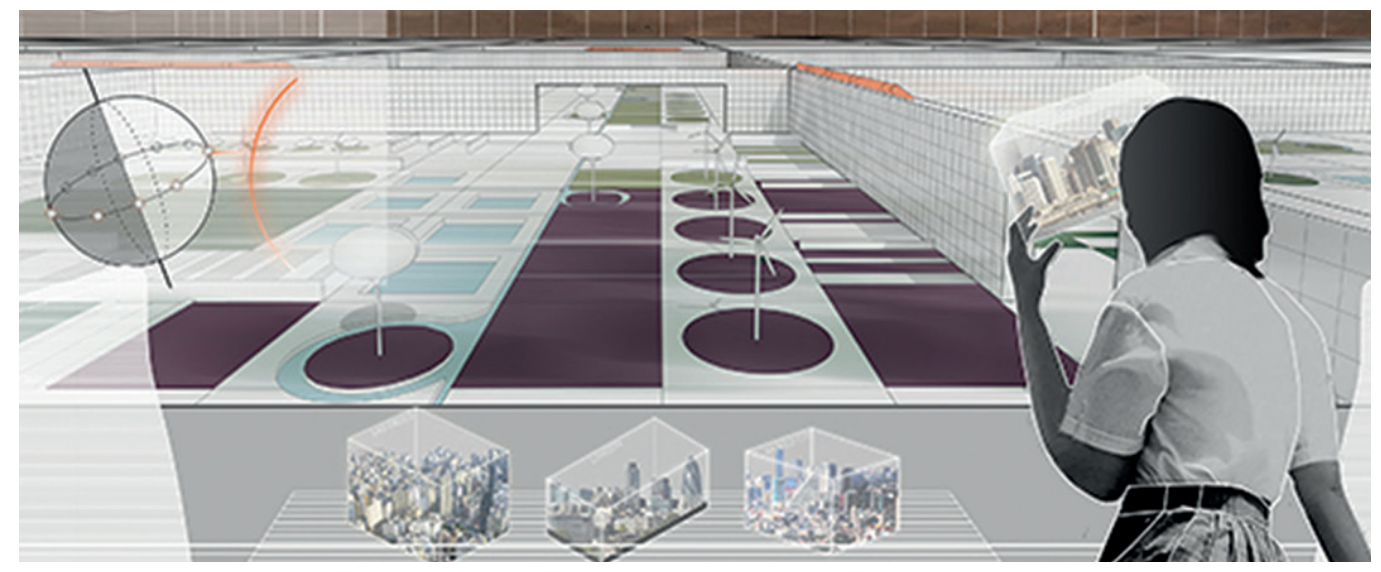




\section{Introduction}

In the past decade millions of people have been uprooted from their homes due to major natural disasters that required immediate assistance and mobilisation. From Hurricane Katrina in the United States (2005) to the earthquake and tsunami in Japan (201 I), from Typhoon Haiyan in the Philippines (2013) to the earthquake in Nepal (20I5), from the sandstorm in Turkey (20I5) to the earthquake in Italy (20I6), the consequences of the extreme natural phenomena that have occurred have appeared with all their power in aerial photographic images that showed fully reconfigured areas [Vinitsky 20 I7]. Science philosopher Peter Galison and art historian Caroline A. Jones -although with specific reference to the images produced in the wake of the dramatic environmental disaster linked to the Deepwater Horizon oil rig - argue in their analysis that 'visible technologies', such as spectacular satellite images, tragic close-up photographs, penetrating live images, can capture the attention of users, but fail to communicate the deeper effects of the disaster [Galison, Jones 20 I0, pp. 49-5 I] (fig. I). The dramatic character of such representations conveys a feeling of total impotence until the paradoxical situation in which the aesthetics of the facts are such as to anesthetize the action. At the same time, the communication of extreme natural phenomena, with particular reference to natural phenomena related to climate change, is entrusted to an expert scientific language and while observing their effects on a daily basis, such as rising temperatures, melting glaciers or rising water levels, there is no real perception of the problem in its complexity.

It is in this sense that in an era obsessed with impact communication on the one hand and the abuse of technicalities on the other, a level of communication aimed not so much at transmitting 'exact' information and measurements of predicted phenomena, but rather at transmitting the immeasurable value of the potential effects that such predictions would have in everyone's life, becomes paramount. As proven by a series of recent experiences which, although heterogeneous in terms of the instruments used, share the intention of

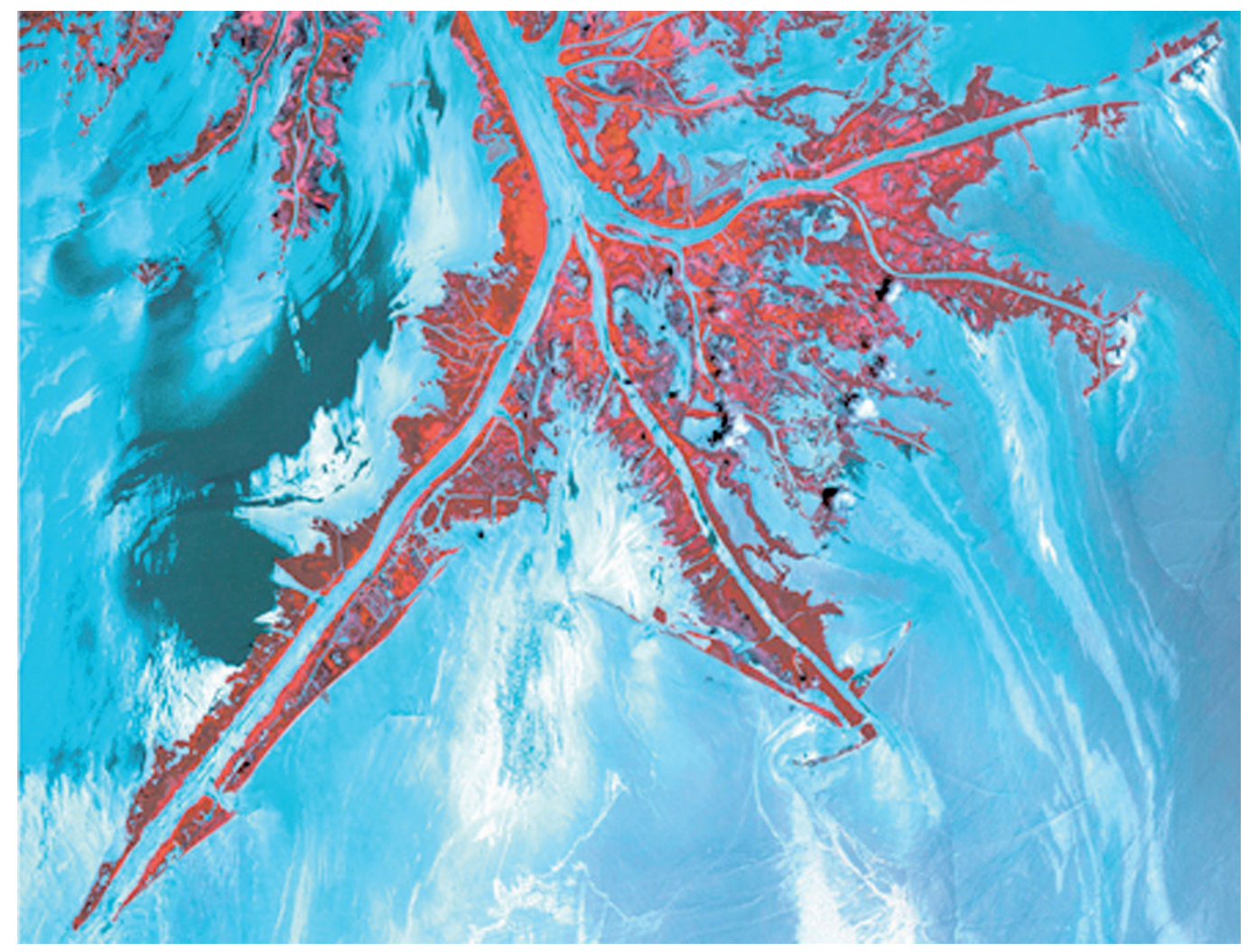


bringing an apparently abstract problem back to a dimension of everyday life, making its possible effects tangible and encouraging concrete actions for change.

Among these Warming Stripes, the graphic pattern created by British climatologist Ed Hawkins and composed of vertical bands that, through blue and red color variations, associated respectively with below -and above- average temperatures, intuitively illustrate the increasing trend of the global average temperature between I 870 and 2017 [I] (fig. 2); Totemy, the installation by Polish designer Alicja Biała and Polish architect Iwo Borkowicz, in which climate change data is reinterpreted in graphic patterns that mark the surfaces of six imposing totems located close to the Bałtyk tower in the city of Poznań (fig. 3); Acqua Alta: En Clave de Sol, the sound design installation by the Argentinean artist Tomàs Saraceno at the 58th International Art Exhibition, in which, superimposing on a musical score the graph of the high tide expected in Venice in the next hundred years, the sound of alarm sirens is imagined in the context of a completely submerged city (fig. 4); $+1,5{ }^{\circ} \mathrm{C}$ Lo cambia todo, the videosimulation campaign promoted by WWF together with the Prado Museum, in which some of the most famous works of the Spanish museum's collection are imagined in
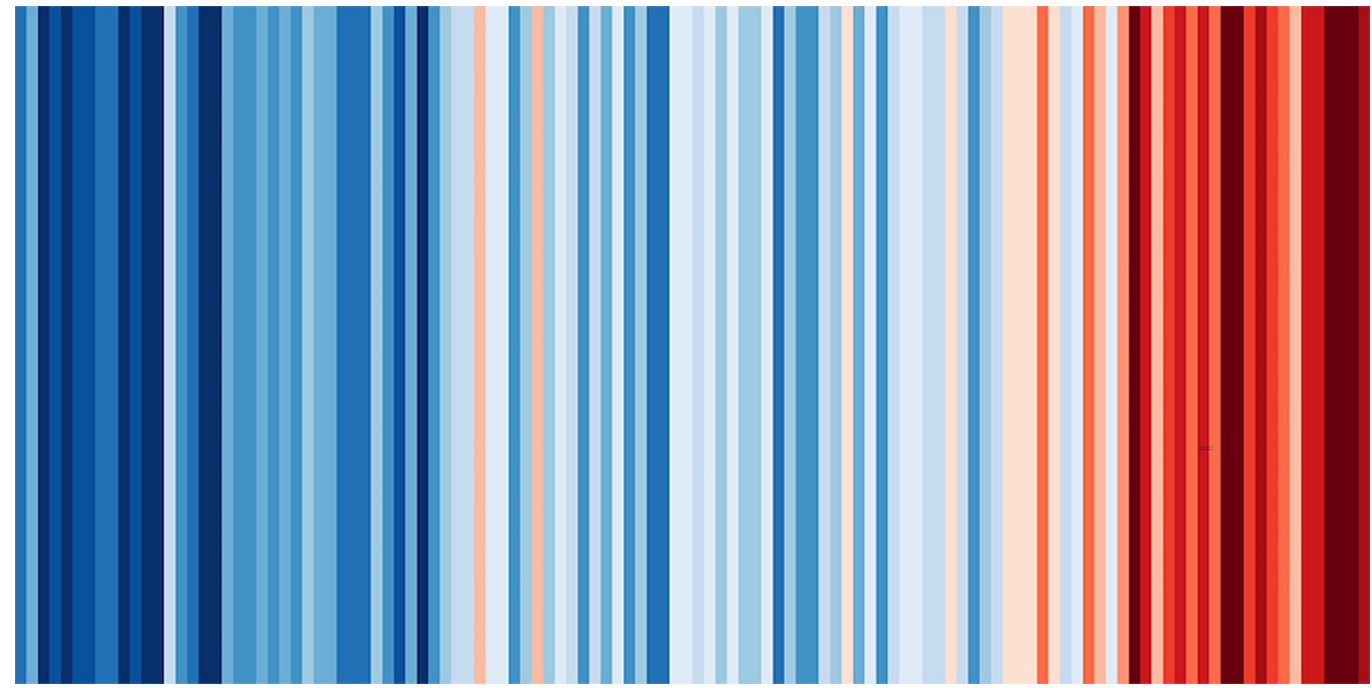

Fig. 3. Alicja Biała and Iwo Borkowicz, Totemy, installation detail.

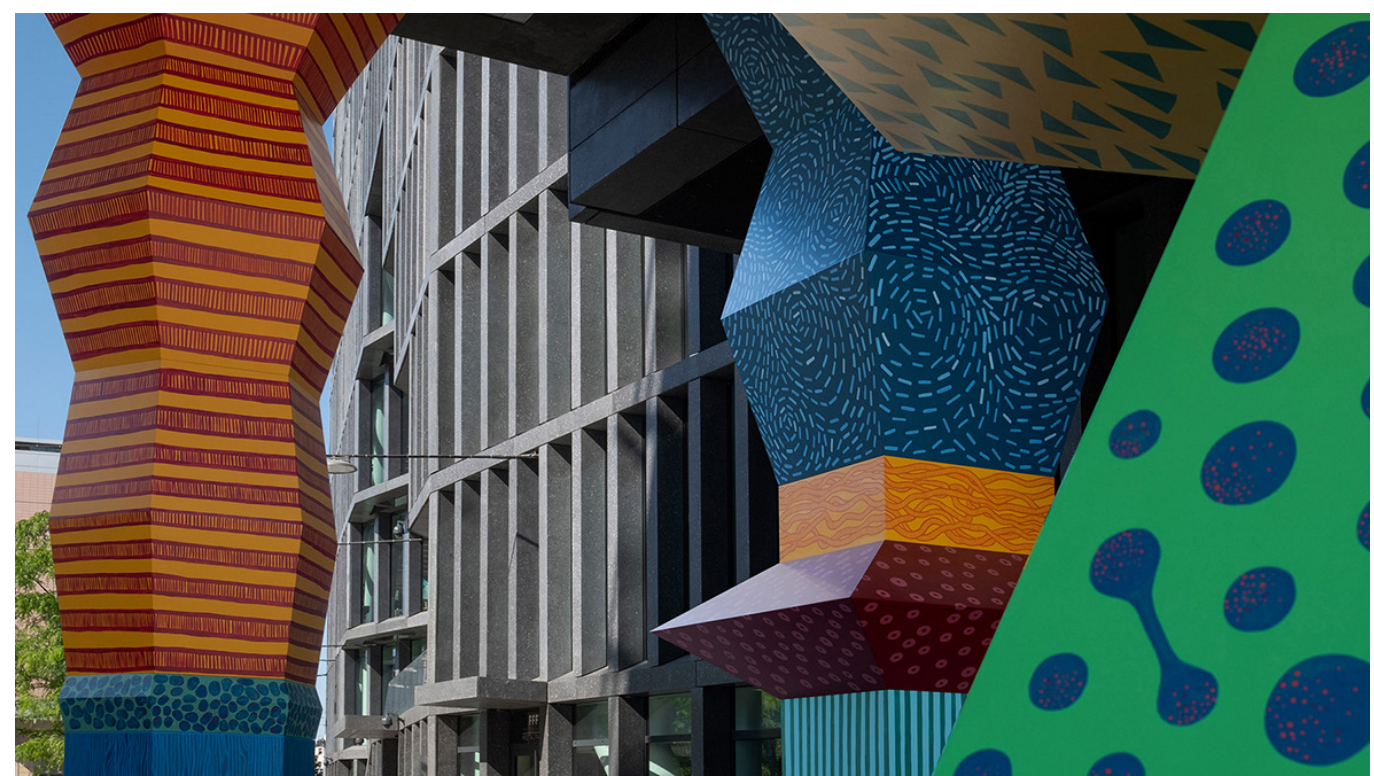


a future in which the temperature on the planet will rise by $1.5^{\circ} \mathrm{C}$ : a figure only apparently negligible because it is such as to submerge Philip IV on horseback in the homonymous portrait signed by Diego Velázquez [2] (fig. 5). Finally, Flooded London [3], the series of infographic simulations in which the digital design group Squint Opera imagines the city of London in 2090, illustrating to citizens how an apparently abstract concept, such as climate change, can influence daily life: and so, the catastrophic rise in temperature and sea level will allow the possibility of a dive into the flooded nave of St Paul's Cathedral (fig. 6).

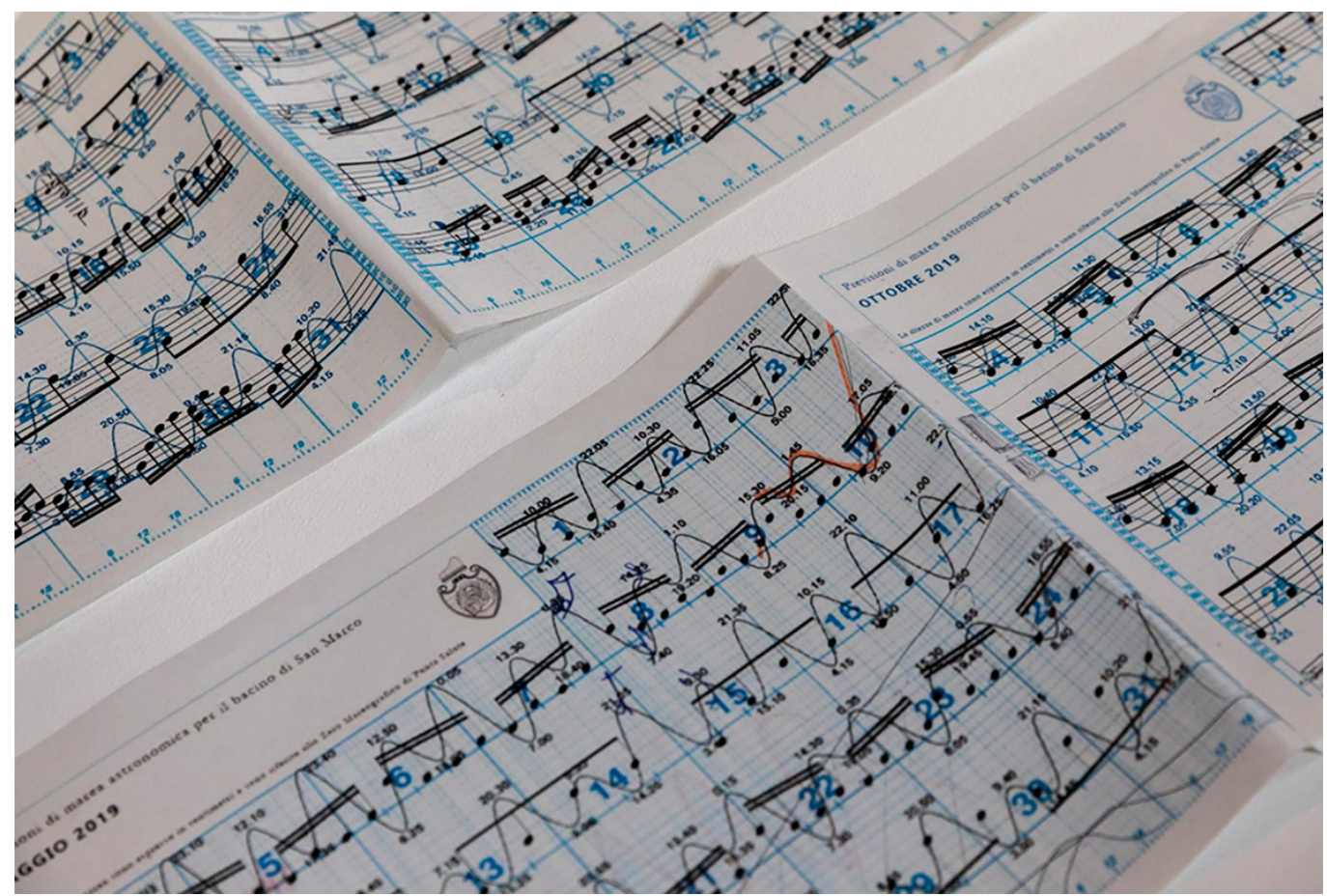

\section{Living inside}

In 1928 Gio Ponti dedicated the opening editorial of the first issue of the magazine Domus to the theme La casa allitaliana in which he stated how the peculiar character of national culture was expressed by the search for its own domestic landscape, whose characteristics were identified in the abolition of any distinction between inside and outside. It is in fact Gio Ponti himself who affirms that "the Italian-style house is not the shelter, padded and garnished, of the inhabitants against the harshness of the climate as it is of the homes beyond the Alps where life seeks, for long months, shelter from the inclement nature: the Italian-style house is like a place chosen by us to enjoy in our lives, with joyful possession, the beauty that our lands and skies give us in long seasons. In the Italian style house there is no great distinction between outside and inside [...]. From the inside the Italian-style house succeeds outdoors with its porches and terraces, with pergolas and verandas, with loggias and balconies, altane and belvedere, all very comfortable inventions for a peaceful home and so Italian that in every language are called with names from here" [Ponti 1928, p. I8; Irace 2019, pp. 40-46]. However, about a century later, the environmental effects on the life of the planet -from the onset of high temperatures to the spread of epidemics- call for an urgent need for conscious planning. On the contrary, the price to pay will be very high. One need only think of the forecasts linked to the rise in water levels. New York, Rio de Janeiro, Alexandria, Pisa, Ravenna, Venice, Bari are just some of the cities located near the 
Atlantic, Mediterranean, Tyrrhenian or Adriatic coasts which, according to a study published by the international organization Climate Central [4], will be submerged by water over the next decade, with an increase in temperature from 2 to 4 degrees Celsius (fig. 7). So the house of the future, be it on the coasts of the peninsula and in other parts of the world, rather than adhering to Gio Ponti's description, approaches the interpretation of the French philosopher Gaston Baschelard, that is, the house of refuge, den or shell. It is in this way that actions such as limiting, enclosing, or circumscribing, constitutive of the internal space, are moved by a feeling of "claustrophilia" [Fachinelli 1983, pp. 62-64] dictated by the "search for the closed" and implemented in opposition to an external region seen as dangerous, hostile and literally unlivable.

Fig. 5. $+1,5^{\circ} \mathrm{C}$ Lo cambia todo, excerpt from the videosimulation campaign.

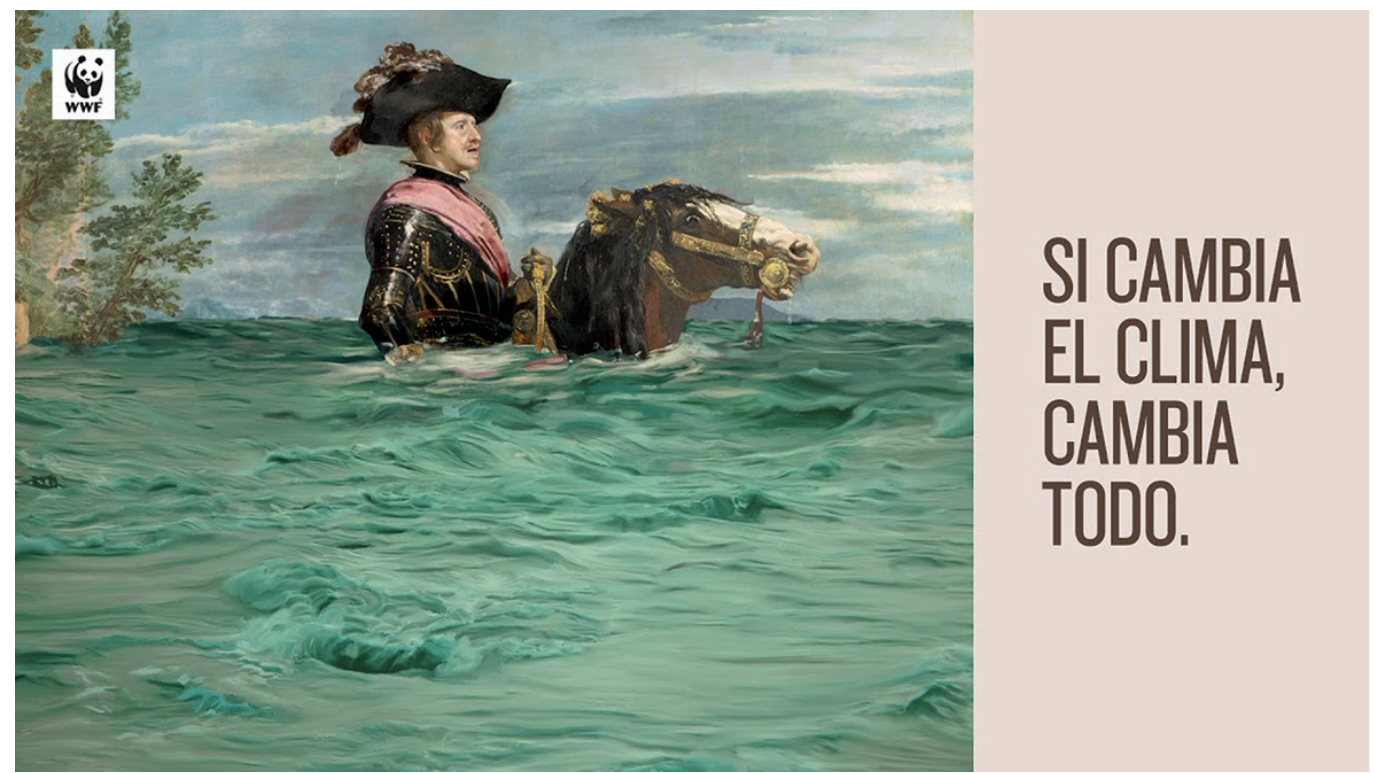

In this sense the project Airpocalypse signed by El Hadi Jazairy and published in the volume Geostories. Another Architecture for the Environment [Ghosn, Jazairi 2018] seems extremely interesting. The project is a visionary response to the air pollution crisis that hit the city of Beijing in 2014 and that continues to affect many of the most industrialized areas of China. In January 2014, the city of Beijing was subjected to twenty-six consecutive days of heavy smog: the air became so dense that it was impossible to see the sun. The images of the crowd around a giant screen in Tienamen Square awaiting the sunrise broadcast are now well known. An event that has been disseminated by the international press with the title The dawn will be broadcast on television! and which is emblematic of the now tangible risk of not being able to consider the possibility of breathing as a matter of course. So, considering the weather conditions of a city hit by a heavy assault of smog, how can we imagine the structures necessary to make life possible on a land deprived of sun and atmosphere? The response conveyed by Airpocalypse is to enclose within limited boundaries the world population occupying urban areas. A megalopolis conceived as a large, circumscribed and livable interior, subject to climate control thanks to the presence of an atmospheric habitat, a greenhouse, a biosphere and a spaceship. On the dashboard of the spacecraft, a series of 'snowballs' encloses some miniaturized urban scenes, from Chicago to Mexico City, from London to Sao Paulo, including renewable portions of the landscape (fig. 8).

Or the Mars Science City project (fig. 9), the first prototype on earth for a future life on Mars, developed by the international design studio BIG and currently under construction in Dubai [5]. The project envisions a future scenario in which, in order to protect the Earth's resources, humanity will move to the planet Mars. How to deal with adaptation to the local climate 
and landscape, characterized by low gravity, low pressure, extreme cold and high levels of radiation? One of the possible ways to redesign living space is to build a large interior that includes and stratifies different elements. In particular, these are large interconnected inflatable geodesic domes (resulting from the combination of three construction technologies, namely pressostructures, 3D printers and underground structures), capable of protecting against harmful radiation and preserving an ecosystem on a human scale. It is interesting to note that in both Airpocalypse and Mars Science City the separation between a threatening exterior and a reassuring interior occurs through 'transparent' surfaces. In this light, the words of the American architect and academic Georges Teyssot about the "apparent transparency" of 19th century architecture seem more relevant than ever. A transparency "which in reality is purely superficial: since the buildings themselves are nothing more than large spaces that create 'vast intérieurs' for the community, so large that they do not have a proper exterior" and the public spaces "become as many 'internal', formed in many cases by buildings of various types" [Teyssot 2010, p. 27].

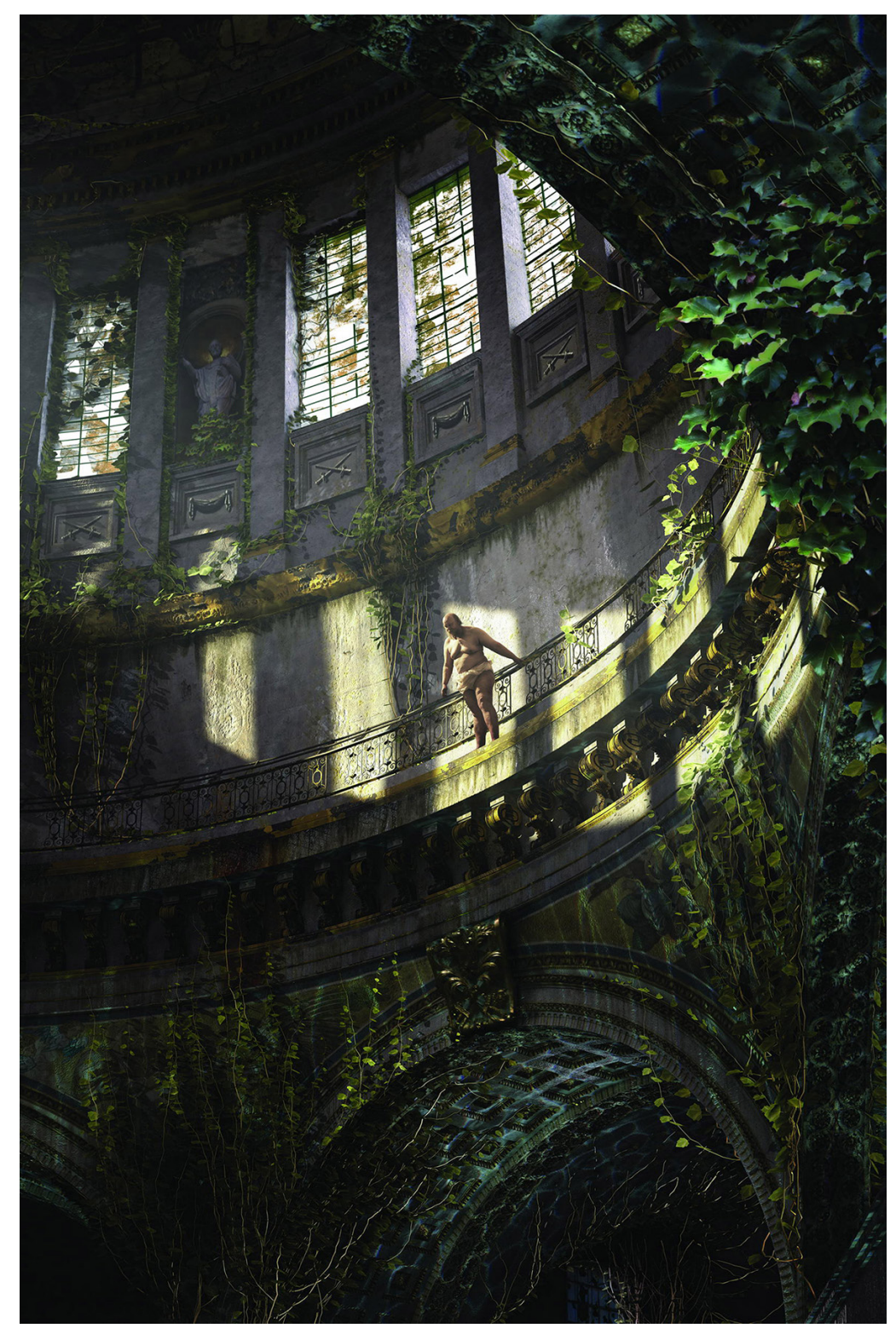




\section{Final remarks}

For the specific purposes of this contribution, the scenarios described open up a question about the relationship between external and internal spatial categories, traditionally referred to the social categories of public and private life respectively. Taking the logic of a scenario in which it is impossible to lead a life outside protected environments, it seems legitimate to hypothesize that the couple of the opposites public-private life, pours into the couple of the opposites inside "inside of the inside". And it is precisely in the latter case, that a condition of intimacy can be achieved. An interpretation which is supported by the observation of the etymological origin of the adjective 'intimate', as is well known, superlative form of the term 'internal' - from the Latin intimus, superlative form of the adjective 'interior' [6]. Therefore, in order to offer a tendentious interpretation of the grammatical category, it is precisely thanks to the gradual passage that denotes the superlative form, the "inside of the inside", that a condition of increasing intimacy can be achieved. It is to be hoped that this protection will encourage new imaginative actions, in response to a pragmatic commitment that is now unavoidable. On the other hand, borrowing the thought expressed by Gaston Bachelard: "sure, you feel that you are faced with a mixed problem of imagination and observation. [...] We simply want to show that, as soon as life is established, protected, covered, hidden, the imagination sympathizes with the being who inhabits the protected space. [...] Does being sheltered under a color mean to take to the extreme, to the point of imprudence, the tranquility of living?" [Bachelard 1957, p. 163].
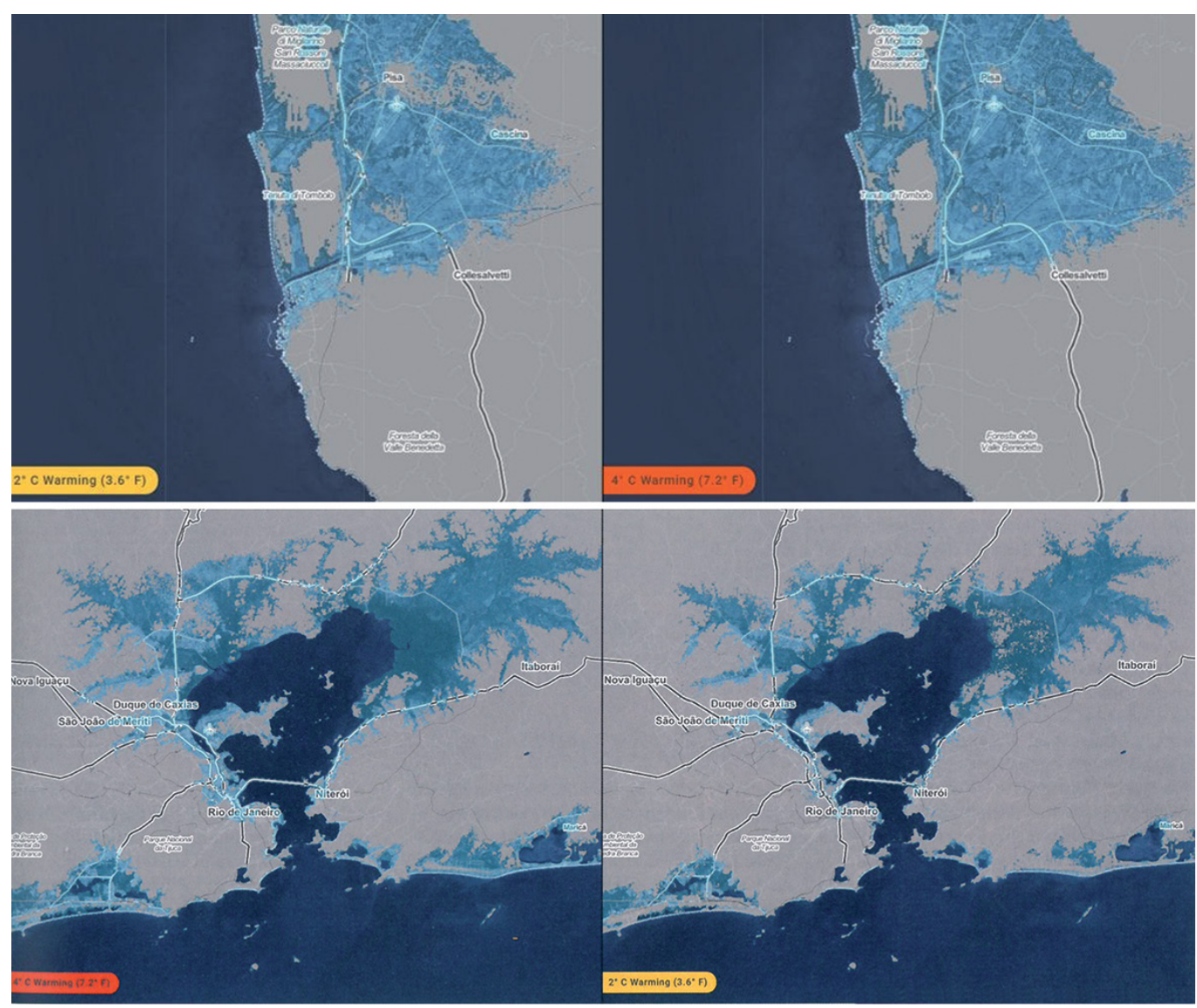
Fig. 8. El Hadi Jazairy,

Airpocalypse, view of the megacity.

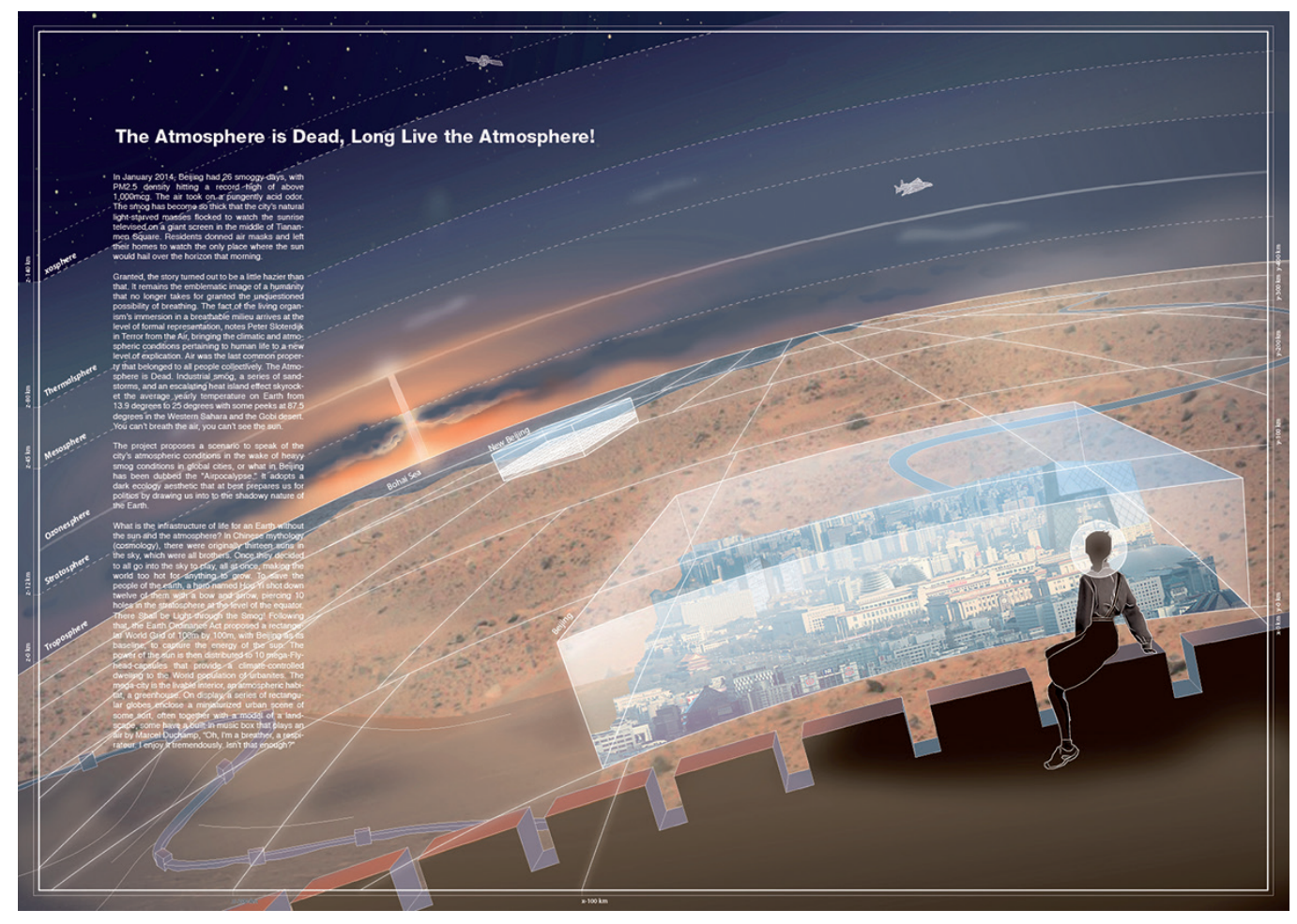

Fig. 9. BIG, Mars Science City, view of the pressostructures.

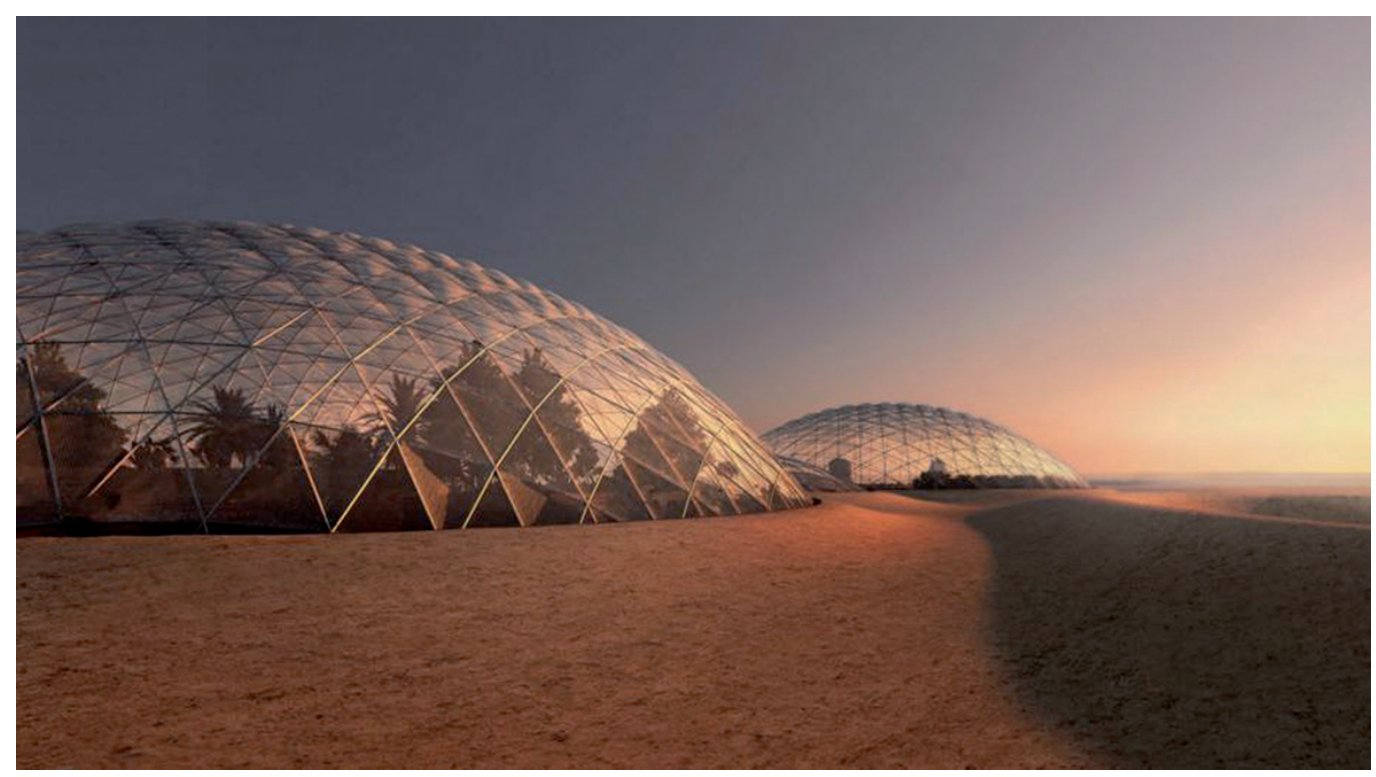




\section{Notes}

[I] Le Warming Stripes-identità visiva Waste Mob 20/9: <https://www.youtube.com/watch?v=JzGWvg3NdUc>.

$[2]+1,5{ }^{\circ} \mathrm{C}$ Lo cambia todo: <https://www.wwf.es/nuestro_trabajo/clima_y_energia/cumbres_del_clima/cop_25_chile_ madrid_locambiatodo/>.

[3] Flooded London: <https://www.dezeen.com/2019/07/23/flooded-london-squint-opera-climate-change/>.

[4] Surging Seas Extreme Scenario 2100: <https://sealevel.climatecentral.org/maps/P5>.

[5] Mars: <https://big.dk/\#projects-mars>.

[6] Intimo (ad voce). In Vocabolario Treccani: <http://www.treccani.it/vocabolario/intimo/>.

\section{References}

Bachelard Gaston (20I5). La poetica dello spazio. Bari: Dedalo. (Ed. orig. La poétique de l'espace. Parigi: Presses Universitaires de France, 1957)

Belardi Paolo (a cura di). (20 I 8). Riflesso Emergency. Magazine sulla Cultura delle Emergenze.

Bergdoll Barry (20 I9). Abbiamo bisogno della ricerca. Research is needed. In Domus, I040, p. I I 2 I - I 127.

Fachinelli Elvio (1983). Claustrofilia. Saggio sull'orologio telepatico in psicanalisi. Milano: Adelphi.

Forino Imma (200 I). L'interno nell'interno. Una fenomenologia dell'arredamento. Firenze: Alinea.

Galison Peter, Jones Caroline A. (20 I0). Unknown Quantities on oil spill imaging. In Artforum International, n. 49, pp. .49-5I.

Ghosn Rania, Jazairy El Hadi (20 I 8). Geostories. Another Architecture for the Environment. New York, Barcellona: Actar.

Irace Fulvio (a cura di). (2019). Storie d'interni. L'architettura dello spazio domestico moderno. Roma: Carocci.

Ponti Gio (1928). La casa all'italiana. In Domus, n. Ip. 7.

Teyssot Georges (20 I0). Soglie e pieghe. Sull'intérieur e l'interiorità. In Casabella, 68I, 200 I, pp. 26-35.

Teyssot Georges (a cura di). (1987). Paesaggio d'interni. Milano: Electa.

Vinitsky Maya (2017). 3.5 Square Meters: Constructive Responses to Natural Disaster. A Research Project and Exhibition. Tel Aviv Museum of Art: HIRMER Publishers.

Weizman Eyal,Weizman Ines (20I4). Before and after. Documenting the architecture of disaster. Strelka Press

\section{Author}

Giovanna Ramaccini, Università degli Studi di Perugia, giovanna.ramaccini@unipg.it

To cite this chapter. Ramaccini Giovanna (2020). L'ambiente visto dall'interno: abitare il cambiamento climatico/The environment from inside. In Arena A., Arena M., Brandolino R.G., Colistra D., Ginex G., Mediati D., Nucifora S., Raffa P. (a cura di). Connettere. Un disegno per annodare e tessere. Atti del $42^{\circ}$ Convegno Internazionale dei Docenti delle Discipline della Rappresentazione/Connecting. Drawing for weaving relationships. Proceedings of the 42th International Conference of Representation Disciplines Teachers. Milano: FrancoAngeli, pp. 3738-3755. 